\title{
Passivation Layer Stability of a Metallic Alloy Waste Form
}

\section{Fuel Cycle Research \& Development}

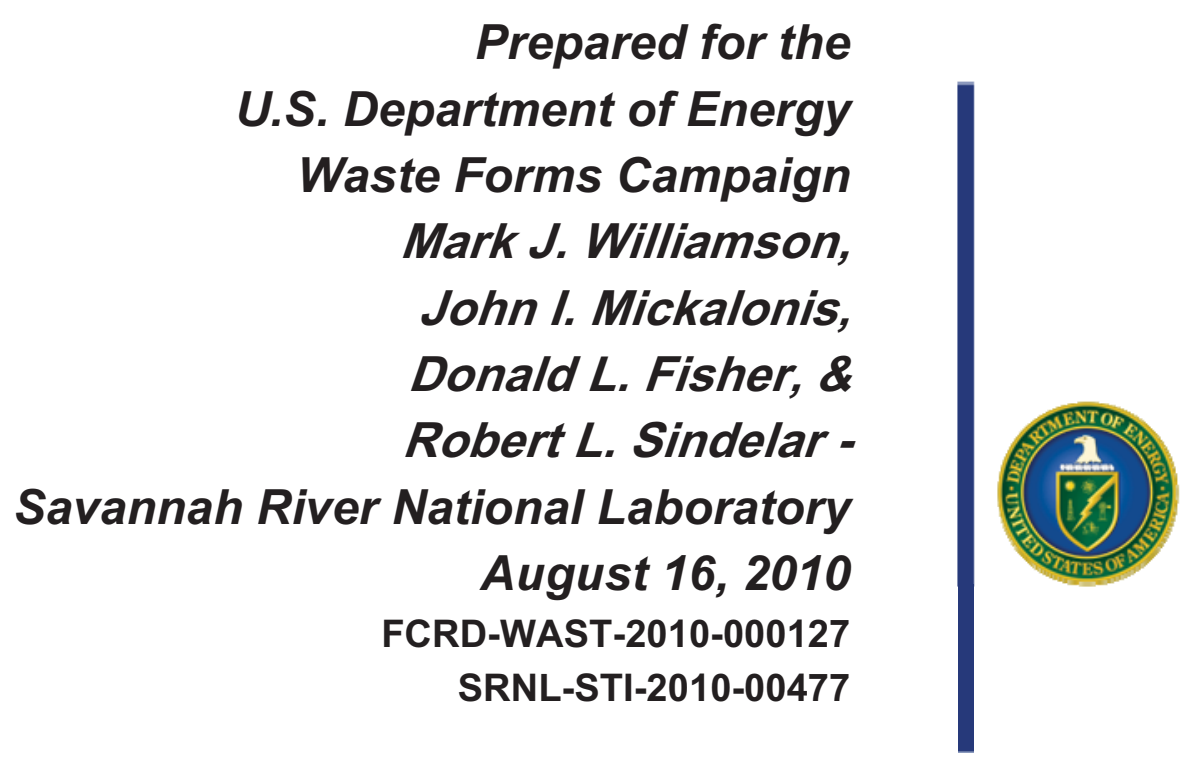




\section{DISCLAIMER}

This information was prepared as an account of work sponsored by an agency of the U.S. Government. Neither the U.S. Government nor any agency thereof, nor any of their employees, makes any warranty, expressed or implied, or assumes any legal liability or responsibility for the accuracy, completeness, or usefulness, of any information, apparatus, product, or process disclosed, or represents that its use would not infringe privately owned rights. References herein to any specific commercial product, process, or service by trade name, trade mark, manufacturer, or otherwise, does not necessarily constitute or imply its endorsement, recommendation, or favoring by the U.S. Government or any agency thereof. The views and opinions of authors expressed herein do not necessarily state or reflect those of the U.S. Government or any agency thereof. 


\section{SUMMARY}

Alloy waste form development under the Waste Forms Campaign of the DOE-NE Fuel Cycle Research \& Development program includes the process development and characterization of an alloy system to incorporate metal species from the waste streams generated during nuclear fuel recycling. This report describes the tests and results from the FY10 activities to further investigate an Fe-based waste form that uses 300-series stainless steel as the base alloy in an induction furnace melt process to incorporate the waste species from a closed nuclear fuel recycle separations scheme. ${ }^{\mathrm{a}}$

This report is focused on the initial activities to investigate the formation of oxyhydroxide layer(s) that would be expected to develop on the Fe-based waste form as it corrodes under aqueous repository conditions. Corrosion tests were used to evaluate the stability of the layer(s) that can act as a passivation layer against further corrosion and would affect waste form durability in a disposal environment.

\section{Alloy Waste Form with 300-Series Type Stainless Steel - Processing and Structure}

Induction furnace melts ( 50 gram per batch) were made under vacuum at a process temperature of $1600^{\circ} \mathrm{C}$ for compositions with non-radioactive surrogates of $\mathrm{Zr}, \mathrm{Mo}, \mathrm{Re}$ (a surrogate for Tc-99), $\mathrm{Ru}, \mathrm{Rh}$, $\mathrm{Pd}$, and $\mathrm{Sn}$ in the relative ratios expected from separations processing of a reference fuel ${ }^{\mathrm{b}}$ and with a 47 $\mathrm{wt} \%$ loading of $304 \mathrm{~L}$ stainless steel or $316 \mathrm{~L}$ stainless steel that yields an effective $53 \%$ waste-specie loading. All surrogate species dissolved into the melt at the process condition and were incorporated into intermetallic or solid solution phases as the melt cooled.

A total of four primary phases was common to the melts with 304L stainless steel and 316L stainless steel as identified by EDS analysis. The phases were characterized as Fe-Mo, Zr-Mo, Fe-rich, and Pd-rich phases that are most likely the Laves phase $\mathrm{Fe}_{2} \mathrm{Mo}$; $\mathrm{C} 36$ and $\mathrm{C} 15$ polytypes of $\mathrm{Fe}_{2} \mathrm{Zr} ; \gamma$-Fe solid solution phase, and a Pd-rich phase (perhaps $\mathrm{Pd}_{2} \mathrm{Zr}$ ) based on similar compositions with the phases identified in the previous melts made with pure Fe. All four phases from the pure Fe melts were present in the melts made with the stainless steels. The preliminary results suggest however that the Fe phase is $\gamma$-Fe (fcc) due to its high nickel content $>10$ at $\%$ that remains with this phase in the assemblage and that would stabilize austenite. The $\alpha$-Fe (bcc) phase is the Fe solid solution phase that formed in the Fe-based waste form material made with pure Fe in FY09. Similar to the alloy melts made with pure Fe, each of the surrogate waste metal species from the stainless steel melts were incorporated into one or more of these phases in concentrations nearly identical to those in materials made with pure Fe.

A stabilization treatment was added to the processing conditions for the Fe-based alloy. A 1-hour hold at $1000^{\circ} \mathrm{C}$ was added during the melt cool-down. This resulted in a coarse microstructure (larger grains) compared to the microstructure of phases that formed during the continuous cool-down ramp from the $1600^{\circ} \mathrm{C}$ melt temperature to $500^{\circ} \mathrm{C}$ at $10^{\circ} \mathrm{C} /$ minute.

${ }^{a}$ The uranium extraction aqueous and the Echem processing baseline strategies include several waste streams with species that are candidates for an alloy waste form. In aqueous processing, the initial acid dissolution of the fuel includes metal species termed UDS (Undissolved Solids) UDS that include primarily $\mathrm{Zr}, \mathrm{Mo}, \mathrm{Tc}, \mathrm{Ru}, \mathrm{Rh}$, and Pd species. Soluble Tc is also recovered as a separate waste specie from the UREX acid solution (following uranium extraction) using anion exchange. The TMFP (Transition Metal Fission Products) from the TRUEX (Transuranic Extraction) raffinate waste stream, which originate primarily as oxides, include the same species as the UDS, and additionally include Sn and other minor species. Echem processing results in similar metallic species for an alloy waste form.

${ }^{\mathrm{b}}$ The reference fuel is a Light Water Reactor fuel burned to $51 \mathrm{GWd} / \mathrm{MTHM}$ with 20-year cool. 


\section{Passivation Layer Growth and Characterization}

Specimens from the waste form using $316 \mathrm{~L}$ stainless steel were exposed to saturated water vapor at $200^{\circ} \mathrm{C}$ for 7,14 , and 28 days. The edges of the oxide were not readily resolvable due to edge charging effects, and therefore the oxide thickness was not quantified using SEM for analysis of the specimens in cross section. Qualitatively, however, oxyhydroxide layers or oxide films formed in increasing thickness as a function of exposure time with the 28 day specimen exhibiting the thickest layer. Oxide films formed over all the phases except for the Pd-rich phase. Also noted was that the high Re-bearing phase, the Fe-Mo phase, showed markedly less Re uptake in the oxide film.

\section{Waste Form Corrosion Behavior and Passivation Effects}

Two sets of electrochemical tests were conducted with fresh and oxidized specimens. The first set included Open-Circuit Potential (OCP) monitoring, and Linear Polarization Resistance (LPR) and Cyclic Potentiodynamic Polarization (CPP) testing of specimens cut from the 316L stainless steel and 304L stainless steel waste form materials for comparison to the response from previous tests of specimens made with pure $\mathrm{Fe}$ in FY09. The tests, run at room temperature and $\mathrm{pH}$ levels of 3 (using nitric acid in demineralized water) and 11 (using $\mathrm{NaOH}$ in demineralized water), showed a significant improvement in corrosion resistance by using 316L stainless steel or 304L stainless steel as the iron source that is ascribed to the passivation of the Fe phase by chromium supplied by the steels.

The second set of electrochemical tests were performed on the 7- and 28-day oxidized specimens of the 316L stainless steel waste form material to evaluate the effect of the oxide layer on the electrochemical response. Open Circuit Potential (OCP), Linear Polarization Resistance (LPR), and Cyclic Potentiodynamic Polarization (CPP) tests were run at room temperature and $\mathrm{pH}$ levels of 4 (using sulfuric acid in demineralized water) and 10 (using $\mathrm{NaOH}$ in demineralized water). The oxide was observed to increase the open circuit potential and reduce the anodic current in both the high and low $\mathrm{pH}$ conditions. After these measurements, the specimens were polished to remove the oxide layers and the measurements were repeated on the fresh surfaces. The effect of the oxide to passivate the specimens was clearly evident with the 28-day specimen showing the greatest passivation effects in terms of enobling the material as measured by the OCP, and lowering the corrosion current during linear and cyclic polarization. 


\section{CONTENTS}

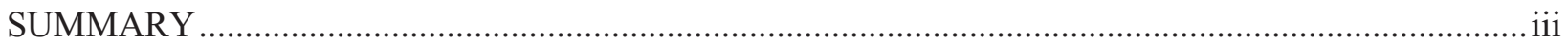

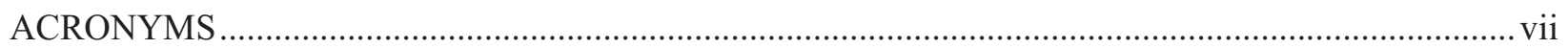

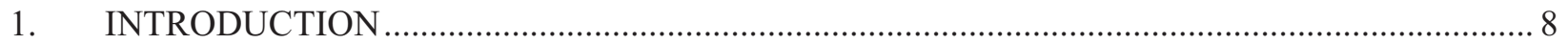

1.1 Scope for Alloy Waste Form Development, Testing, \& Modeling........................................ 8

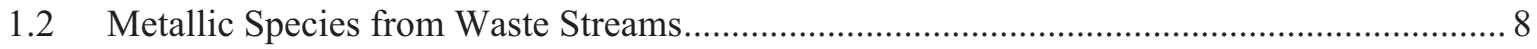

1.3 Waste Form Development with Fe-Based Alloy .......................................................... 9

1.4 Overview of FY2010 Program for Alloy Waste Form Development .................................... 9

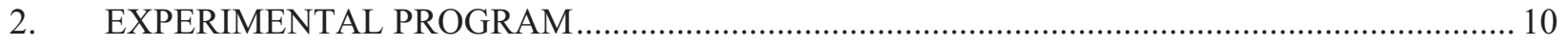

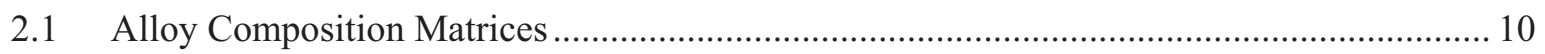

2.2 Starting Materials, Equipment, and Furnace Profiles ..................................................... 10

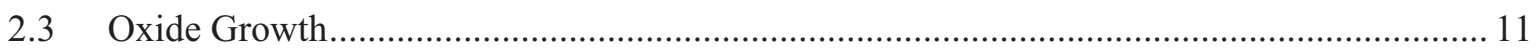

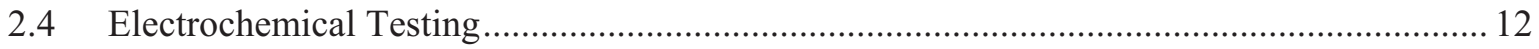

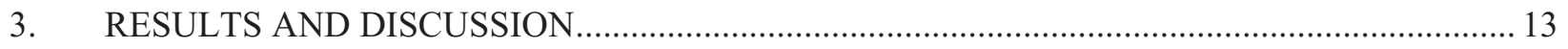

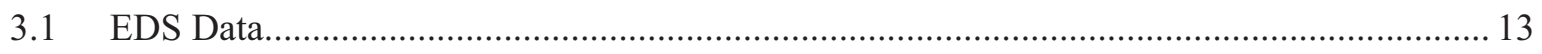

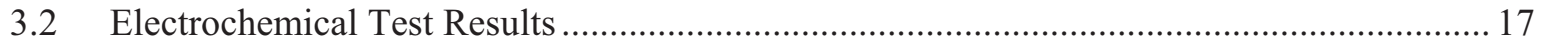

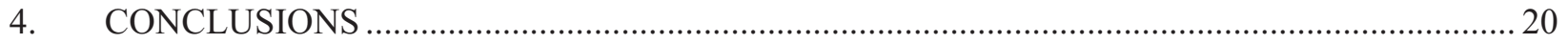

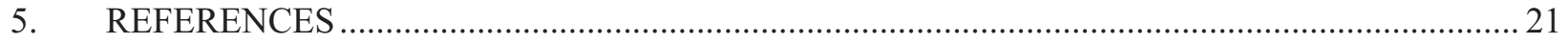




\section{FIGURES}

Figure 1 Plot showing a representative temperature profile for the stainless steel waste form.

Figure 2 Oxidized stainless steel waste form specimens: A) 7 days; B) 14 days; C) 28 days of water vapor exposure in Parr bombs at $200^{\circ} \mathrm{C}$

Figure 3 Electron micrographs of Fe-based alloys with compositions as indicated. The 47SS316 and the 47SS304 specimens were made with $47 \mathrm{wt} \%$ powders of Type $316 \mathrm{LSS}$ and Type 304LSS, respectively. In addition, these specimens were held for approximately 1 hour at approximately $1000^{\circ} \mathrm{C}$ to stabilize the microstructure. White areas are $\mathrm{Pd}$ rich and black areas Fe rich. In the Fe 62 and 60 samples, light and dark gray visually distinguish the $\mathrm{Fe}_{2} \mathrm{Mo}$ and $\mathrm{Fe}_{2} \mathrm{Zr}$; however in the other images both phases are seen as gray.

Figure 4 Plots showing the atomic percent of each element identified by EDS in the four major phases of the Fe-based waste form alloys.

Figure 5 Bulk microstructure of the 28-day oxide specimen. 16

Figure 6 Open-circuit potential measurements of stainless steel alloyed waste forms prior to performing polarization tests.

Figure 7 Cyclic potentiodynamic polarization scans of the stainless steel and iron waste forms. The solutions are $\mathrm{pH} 3$ nitric acid solutions and $\mathrm{pH} 11$ sodium hydroxide solutions. The voltage is against a Saturated Calomel Electrode (SCE) as the reference electrode. $[\mathrm{SCE}$ voltage $+0.045 \mathrm{~V}=\mathrm{Ag} / \mathrm{AgCl}$ voltage $]$.

Figure 8 Cyclic polarization scans for oxidized stainless steel waste forms in basic (top plot) and acidic (bottom plot) solutions.

Figure 9 Composite cyclic polarization scans for the 7-day and 28-day oxidized stainless steel in $\mathrm{pH} 4$ (using sulfuric) and $\mathrm{pH} 10$ (using $\mathrm{NaOH}$ ).

\section{TABLES}

Table 1 Metal species from waste streams (in kg/MTIHM) from a reference fuel assembly using a UREX-type of fuel (uranium) recycle flowsheet with assumed separations efficiencies.

Table 2 Polarization parameters for oxidized, stainless steel alloy waste form specimens

Table 3 Representative EDS data (at.\%) from samples exposed to $200^{\circ} \mathrm{C}$ demineralized water at the indicated times. Data was recorded both at the exposed surface edge and bulk of grains

Table 4 Corrosion Rates and Electrochemical Parameters for Stainless Steel Alloyed Waste

Forms in Acidic and Basic Solutions..... 


\section{ACRONYMS}

$\begin{array}{ll}\text { AFCI } & \text { Advanced Fuel Cycle Initiative } \\ \text { AWF } & \text { Alloy Waste Form } \\ \text { CPP } & \text { Cyclic Potentiodynamic Polarization } \\ \text { EDS } & \text { Energy Dispersive X-ray Spectroscopy } \\ \text { FCR\&D } & \text { Fuel Cycle Research and Development } \\ \text { LPR } & \text { Linear Polarization Resistance } \\ \text { MAWS } & \text { Minimum Additives Waste Stabilization } \\ \text { MTIHM } & \text { Metric Tons Initial Heavy Metal } \\ \text { OCP } & \text { Open-Circuit Potential } \\ \text { SEM } & \text { Scanning Electron Microscope } \\ \text { SNF } & \text { Spent Nuclear Fuel } \\ \text { TMFP } & \text { Transition Metal Fission Products } \\ \text { TRUEX } & \text { Transuranic Extraction } \\ \text { UDS } & \text { Undissolved Solids } \\ \text { UNF } & \text { Used Nuclear Fuel } \\ \text { UREX } & \text { Uranium Recovery by Extraction } \\ \text { XRD } & \text { X-ray Diffraction }\end{array}$




\section{INTRODUCTION}

\subsection{Scope for Alloy Waste Form Development, Testing, \& Modeling}

The Waste Forms Campaign under the Fuel Cycle Research and Development program for the United States Department of Energy, Office of Nuclear Energy is investigating options for waste forms for used nuclear fuel ${ }^{c}$ that will meet the need for economic and sustained nuclear energy production while satisfying requirements for controlled, proliferation-resistant nuclear materials management $[1,2]$.

The work in this report is part of the evolutionary track of the science-based approach for waste form development, testing, and qualification. The Alloy Waste Form working group under the Waste Forms Campaign is developing an alloy waste form for the metallic species and metal oxide contaminants from full recycle waste streams.

The scope of activities for the alloy waste form centers on the development of a high-waste-loading, highdurability alloy waste form(s). The process conditions to create an alloy waste form are developed. The characterization of the waste form in terms of corrosion behavior and release rates (e.g. Tc release rate) are performed to develop a data base to support waste form qualification, and develop a waste form source term model to support performance assessments of repository systems.

The characterization activities include the chemical, radiological, and mechanical durability of the alloy waste form and the component phases. The degradation mechanisms are to be understood under a wide range of repository conditions culminating in a release model to predict long-term behavior under a selected repository condition.

\subsection{Metallic Species from Waste Streams}

In the report, "Global Nuclear Energy Partnership Integrated Waste Management Strategy Waste Treatment Baseline Study"[3], Gombert outlined 12 and 10 waste streams expected from SNF separations processes using aqueous-based and electrochemical-based (Echem) processing, respectively. Several of these waste streams are candidates for a metallic or alloy waste form. These include: 1) Undissolved Solids (UDS), Tc, and Lanthanide and Fission Product Streams from the aqueous processing and 2) Residual Metals and UDS, and Residual Transition Metals and UDS from electrochemical processing. In addition, in both processes cladding materials/hulls and some of the assembly hardware can be incorporated into the melts to stabilize the microstructures of the resulting ingots.

The waste streams with metallic species from the leading aqueous process, the UREX-type process, are the UDS, Tc, and TRUEX ${ }^{\mathrm{d}}$. The Echem and aqueous (UDS + Tc + TRUEX) streams contain essentially the same metals and metal quantities. Table 1 shows estimated compositions of the three waste streams. These predictions are based on $51 \mathrm{GWd} / \mathrm{MTIHM}$ fuel aged for 20 years and separated using a UREX-type

\footnotetext{
${ }^{c}$ Used Nuclear Fuel or Used Fuel (UF) is the term recently adopted by U.S. Department of Energy - Office of Nuclear Energy to reflect that additional energy in the form of enriched uranium and plutonium remain in fuel presently discharged from commercial power reactors, and would be available to be recovered through reprocessing. Fuel that has little or no energy value would be termed "spent."

${ }^{d}$ The TRUEX metallic species originated from the TRUEX raffinate. The metals would results from reduction of the oxides in the raffinate.
} 
process with associated efficiencies. The sum of all of the table elements shows that the total waste loading for the three waste streams is $18.5 \mathrm{~kg} / \mathrm{MTIHM}$.

Table 1 Metal species from waste streams (in $\mathrm{kg} /$ MTIHM) from a reference fuel assembly using a UREX-type of fuel (uranium) recycle flowsheet with assumed separations efficiencies

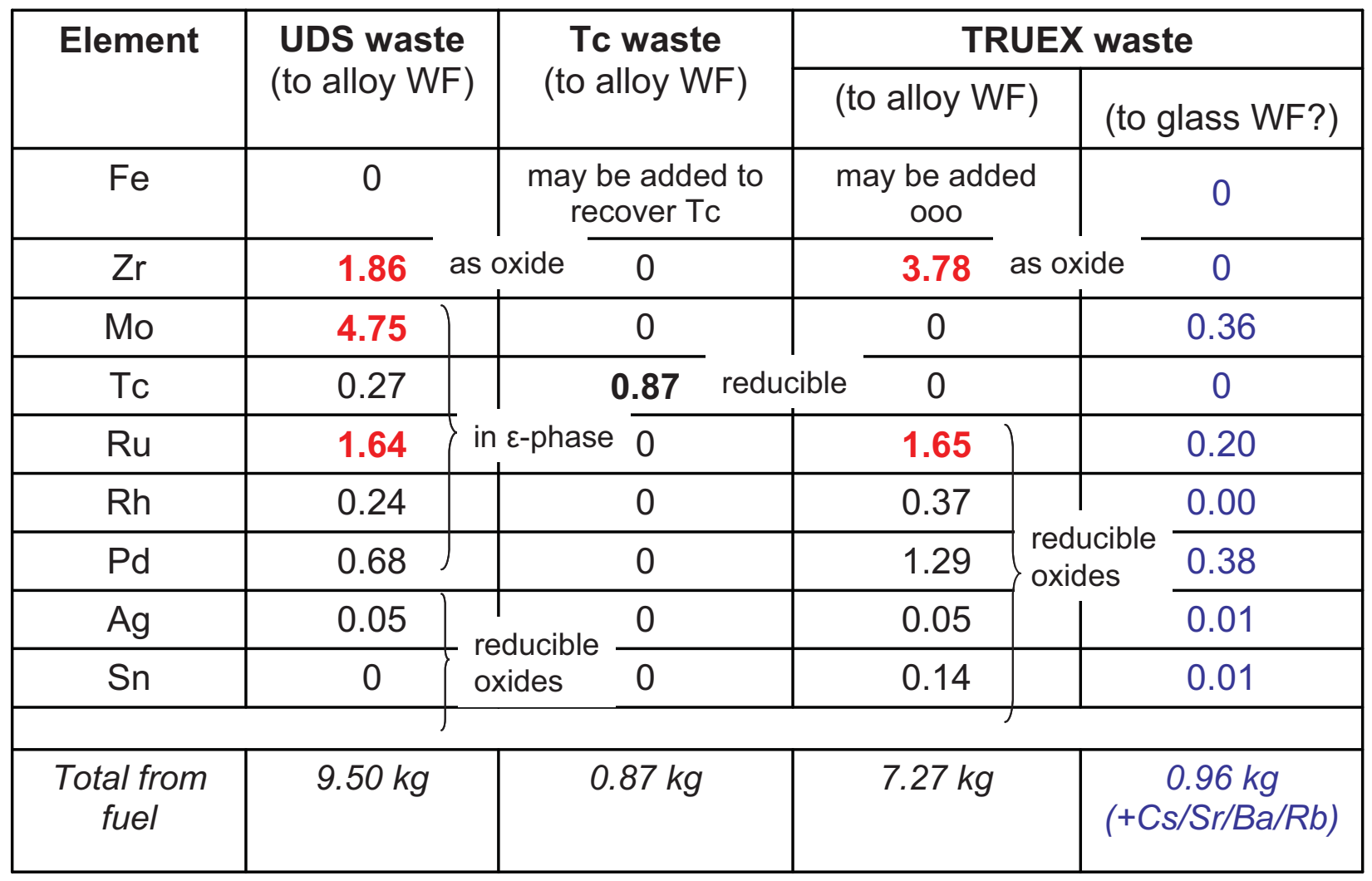

\subsection{Waste Form Development with Fe-Based Alloy}

In 2009 it was demonstrated that an Fe-based alloy waste form, produced using a maximum 1600$1700^{\circ} \mathrm{C}$ melt process, would accommodate the metallic species that represent those from UDS, Tc, and TRUEX waste streams at waste loadings between 37 and 58 percent [4]. The alloys were primarily composed of $\mathrm{Fe}, \mathrm{Fe}_{2} \mathrm{Zr}$ and $\mathrm{Fe}_{2} \mathrm{Mo}$ phases, which accommodated all waste species. Most of the Re, which was used a s a surrogate for Tc, partitioned to the Fe-Mo and Fe solid solution phases.

\subsection{Overview of FY2010 Program for Alloy Waste Form Development}

In order to provide better corrosion resistance to the Fe based alloys the Alloy Waste Form working group began using stainless steel as the Fe source for alloying the waste streams late in the 2009 Waste Forms campaign. Based on the corrosion behavior of stainless steel it was hypothesized that changing from $\mathrm{Fe}$ to stainless would provide very similar waste forms with higher corrosion resistance due to passivating effect of $\mathrm{Cr}$ contributed by the steels.

This report describes the fabrication of stainless steel alloy waste forms and the experimental program to investigate the effects of passivation layers on the corrosion behavior of these alloys.

The FY10 program consists of fabricating a Fe-based alloy using stainless steel with non-radioactive surrogate species based on the waste stream described above. The element Re is used as a surrogate for 
Tc, together with the non-radioactive forms of the other species. Recent results by Buck [5] with a detailed pair-wise comparison of alloys Fe-Mo-Re and Fe-Mo-Tc alloys using transmission electron microscopy analysis show that Re behaves similarly to Tc in its incorporation in the $\mathrm{Fe}_{2} \mathrm{Mo}$ phase. The $\mathrm{Fe}_{2} \mathrm{Mo}$ phase was observed by Buck to be a Laves-type C14 phase.

The preparation of an Fe-based alloy waste form material using 300-series stainless steel as the iron material is described in this report and is compared to the waste form material using pure Fe for the alloy waste form. This report is focused on the initial activities to prepare and characterize oxyhydroxide layer(s) that would be expected to develop on the Fe-based waste form as it corrodes under aqueous repository conditions. The preparation of specimens with oxyhydroxide layers or "oxide films" and the corrosion tests used to evaluate the stability of these films that can act as a passivation layer against further corrosion are described.

This report is in fulfillment of the FCRD FY10 milestone M2503030301.

\section{EXPERIMENTAL PROGRAM}

\subsection{Alloy Composition Matrices}

Previous work has shown that the waste species are incorporated into a melt made by adding $10 \mathrm{~kg}$ of Fe to the UDS + Tc waste from 1 MTIHM. The alloy used for the FY10 work was fabricated using $10 \mathrm{~kg}$ $316 \mathrm{~L}$ stainless steel or 304L stainless steel as a powder. All of the species were scaled to produce $50 \mathrm{~g}$ samples.

\subsection{Starting Materials, Equipment, and Furnace Profiles}

All samples were created with $50 \mathrm{~g}$ total starting material purchased from Alfa Aesar. Zr and Mo slugs were used with 99.5 and 99.95 percent purity, respectively. $\mathrm{Ru}, \mathrm{Rh}, \mathrm{Pd}, \mathrm{Fe}$, and $\mathrm{Re}$ were 22 mesh powders with 99.98, 99.7, 99.995, 99, and 99.999 percent purities, respectively. These powders were loaded into a $50 \mathrm{ml}$ high density alumina crucible for melting. Approximately one half of the stainless steel powder was mixed with the other constituents while the other half was distributed over the top of the melt. This was done to facilitate contact between the molten steel and the waste components, which dissolve into the steel at temperatures well below their individual melting points. The $50 \mathrm{ml}$ crucible was placed inside a larger graphite susceptor which was inserted into the induction coil of a Centorr System VII induction furnace. The temperature of the melt was measured with an optical pyrometer.

A representative temperature profile used for the stainless steel melts is shown in figure 2. The optical pyrometer on the system does not read below $278^{\circ} \mathrm{C}$ and therefore, the furnace was manually controlled to $500^{\circ} \mathrm{C}$. The temperature is automatically ramped from 500 to $1600{ }^{\circ} \mathrm{C}$ at a rate of $10^{\circ} \mathrm{C} /$ minute where it is maintained for 30-60 minutes. Temperature is then ramped to $980^{\circ} \mathrm{C}$ at $10^{\circ} \mathrm{C} /$ minute and maintained for approximately 60 minutes. The final ramp to approximately $500^{\circ} \mathrm{C}$ is also at $10^{\circ} \mathrm{C} / \mathrm{minute}$. Temperature measurements were recorded on a digital data logger (Yokogawa Electric Corp.) at 2 second intervals. No supplemental stirring was applied to the limited convective stirring expected in the crucible. 


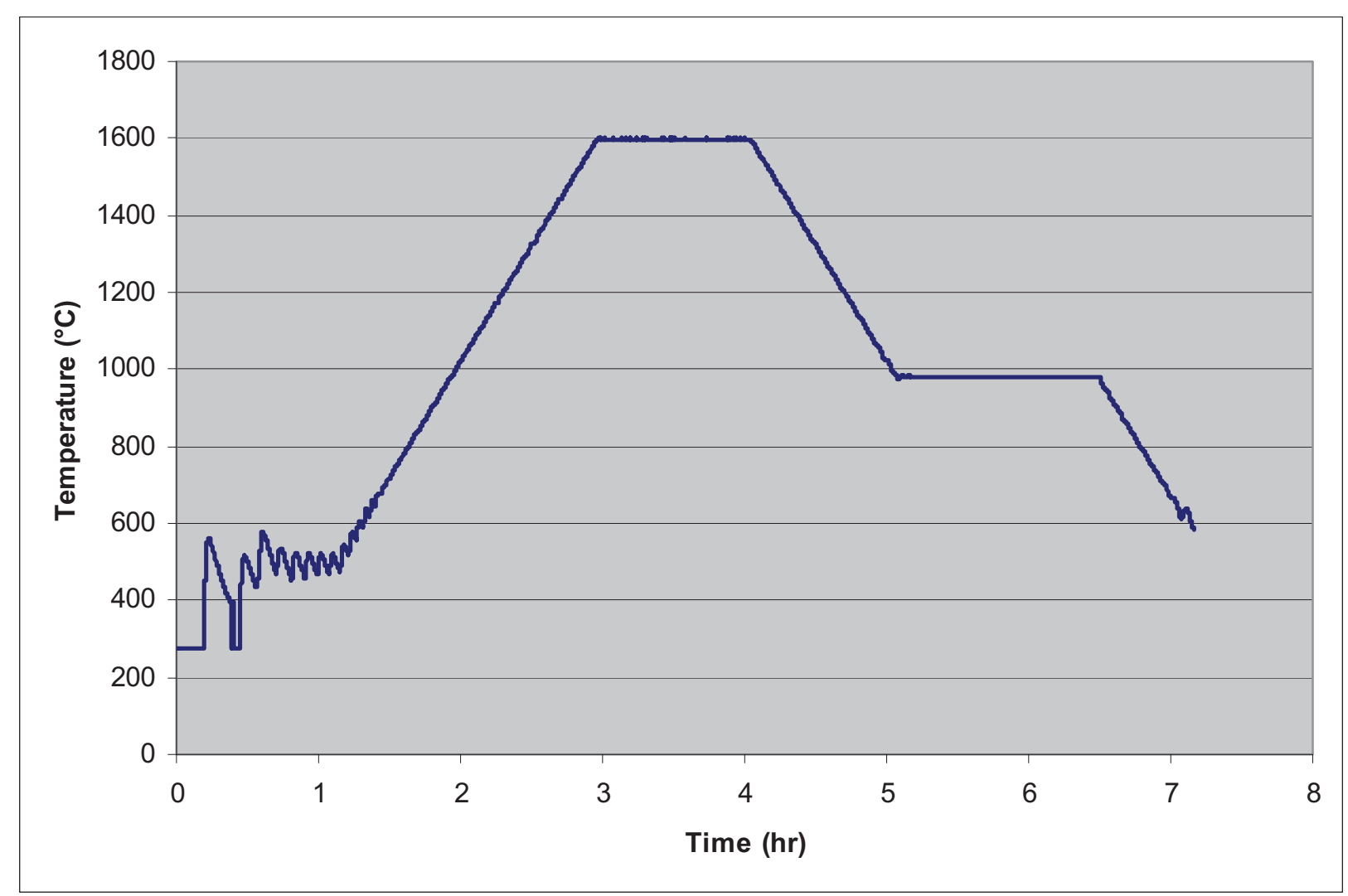

Figure 1 Plot showing a representative temperature profile for the stainless steel waste form.

\subsection{Oxide Growth}

Specimens from the $316 \mathrm{~L}$ stainless steel melt were cut into approximately $25 \times 10 \times 3 \mathrm{~mm}$ rectangular prisms using a Brother HS-78 Electric Discharge Machine. Specimens were then transferred into separate Parr sample preparation bombs with approximately $3 \mathrm{ml}$ of demineralized water. The Parr bombs were then placed in a $200^{\circ} \mathrm{C}$ furnace for 7,14 , and 28 days. The specimens were in the vapor region of the capsule during the exposure. The oxidized specimens are shown in Figure 2.

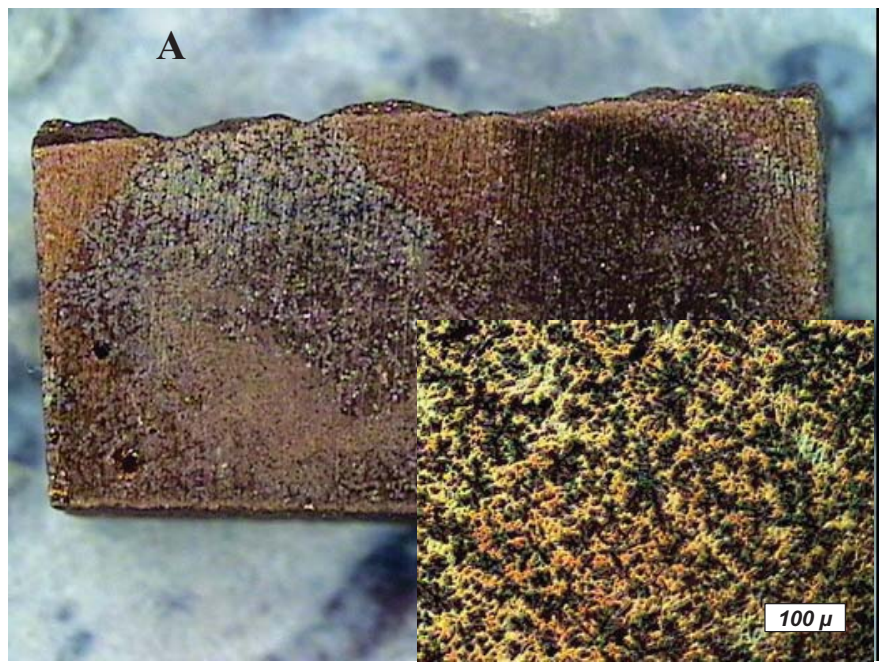



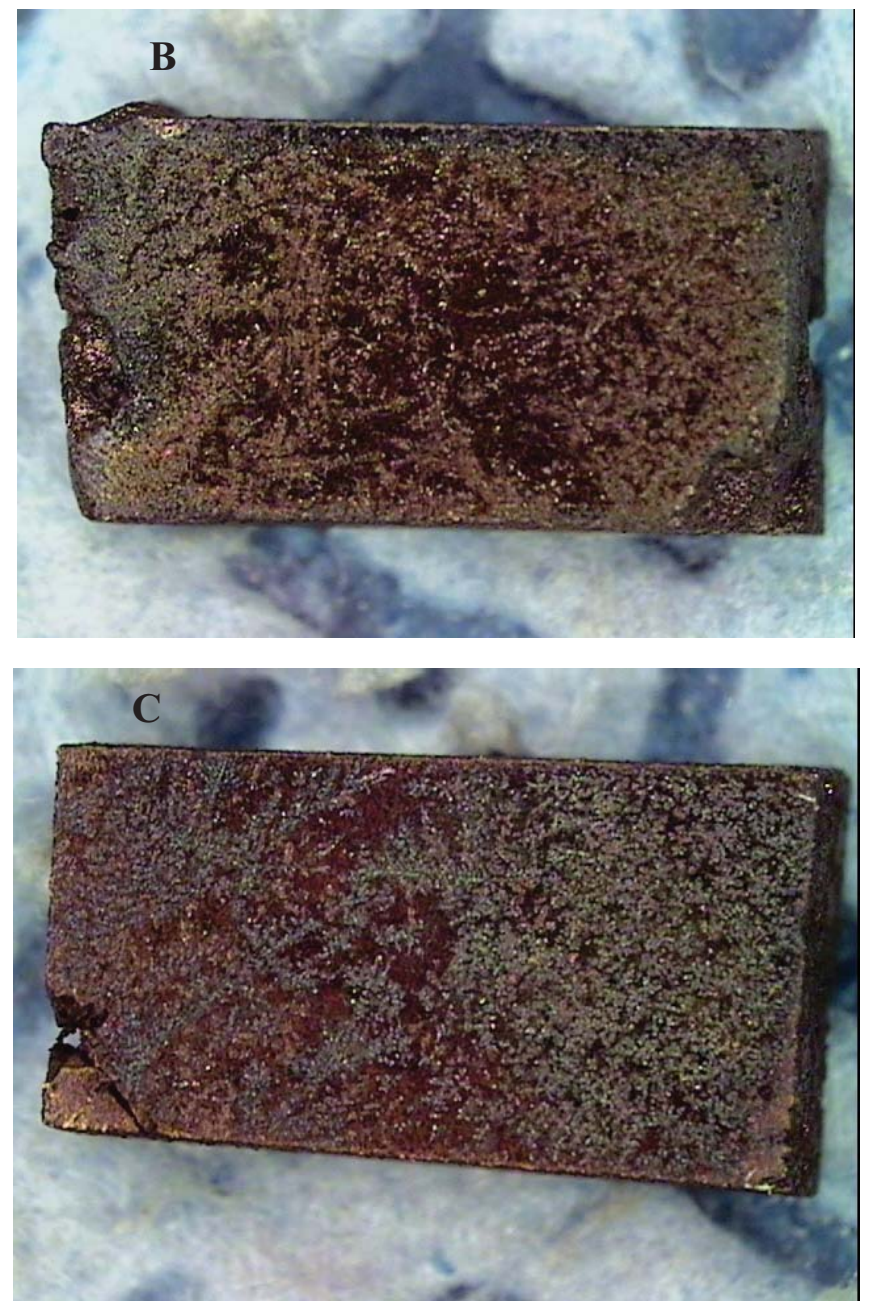

Figure 2 Oxidized stainless steel waste form specimens: A) 7 days; B) 14 days; C) 28 days of water vapor exposure in Parr bombs at $200^{\circ} \mathrm{C}$

\subsection{Electrochemical Testing}

The oxidized samples were prepared for electrochemical testing by placing the samples into metallurgical mounts. A 22-gauge, multi-strand, PTFE-coated wire was attached to one side of the sample with a conductive silver epoxy. For the 14-day specimen, the epoxy seeped onto the oxide face of the specimen so it was not useable.

The specimens were next wrapped in a paraffin-based film prior to mounting in a metallurgical epoxy to protect the surface oxide from bonding with the epoxy. The film was removed from the specimens before placing into the electrochemical test cell. The exposed surface area of each specimen was approximately $0.4 \mathrm{~cm}^{2}$.

The test solutions, $\mathrm{pH} 4$ sulfuric acid solution and $\mathrm{pH} 10$ sodium hydroxide solution, were prepared with reagent grade chemicals in distilled water. Approximately $750 \mathrm{ml}$ of solution was used for each test. Testing was conducted in five-port Greene-type cells. Two 0.25 -in diameter graphite rods were used as counter or auxiliary electrodes. The test reference electrode was a gel-based $\mathrm{Ag} / \mathrm{AgCl}$ electrode with a potential difference from a saturated calomel electrode of $-0.0445 \mathrm{~V}$. Air was bubbled through the solution during the test, which was conducted at room temperature. 
The samples were allowed to stabilize (approximately 2 hours) in the solution prior to performing the electrochemical testing. Linear polarization resistance and cyclic polarization tests were performed on each sample in the two different test solutions. The first linear and cyclic polarization testing was conducted in the $\mathrm{pH} 10$ solution, followed by linear and cyclic polarization tests in the $\mathrm{pH} 4$ solution. The sample was rinsed and dried between tests, but no further surface modifications were performed. The final linear and cyclic polarization tests were performed in fresh $\mathrm{pH} 4$ solution after the sample had been ground with 600-grit paper to remove the oxide surface.

The parameters for the polarization tests are given in Table 2 .

Table 2 Polarization parameters for oxidized, stainless steel alloy waste form specimens

\begin{tabular}{|l|l|l|}
\hline Parameter & Linear & Cyclic \\
\hline Scan rate, $\mathrm{mV} / \mathrm{sec}$ & 0.2 & 0.5 \\
\hline Initial Potential, V vs OC* & -0.015 & -0.01 \\
\hline Vertex Potential, V vs Ref & NA & 1.5 \\
\hline Final Potential, V vs OC & 0.015 & 0 \\
\hline
\end{tabular}

* OC - open-circuit potential, Ref -reference potential

\section{RESULTS AND DISCUSSION}

\subsection{EDS Data}

Figure 3 shows typical SEM micrographs using back-scattered imaging from several samples both from the $2009 \mathrm{Fe}$ samples and the 2010 stainless steel samples. These micrographs highlight the phase assemblage from which elemental composition is determined. The Fe content in the stainless steel samples is approximately $32 \mathrm{wt} \%$ while the total of the $\mathrm{Fe}, \mathrm{Ni}$, and $\mathrm{Cr}$ in these samples is approximately $45 \mathrm{wt} \%$. The morphologies of the low Fe and stainless steel samples are very similar.

Energy dispersive x-ray spectroscopy was used to determine the elemental composition of phases in the melt samples. Six locations were selected on each of the nine samples interrogated. Locations were selected at the center of each sample as well as at the edges. Spectra were recorded at various areas at each of the locations based on image contrast with the goal of recording spectra from each contrast level within the field of view of the microscope.

The EDS data falls into 4 categories with few outliers suggesting four primary phases in the sample. They were hypothesized to be $\gamma-\mathrm{Fe}, \mathrm{Fe}_{2} \mathrm{Zr}, \mathrm{Fe}_{2} \mathrm{Mo}$, and a Pd-rich phase which may be $\mathrm{Pd}_{2} \mathrm{Zr}$. The $\alpha-\mathrm{Fe}$, $\mathrm{Fe}_{2} \mathrm{Zr}$ and $\mathrm{Fe}_{2} \mathrm{Mo}$ results were previously confirmed by XRD in the analysis of the alloy made with pure $\mathrm{Fe}$. 

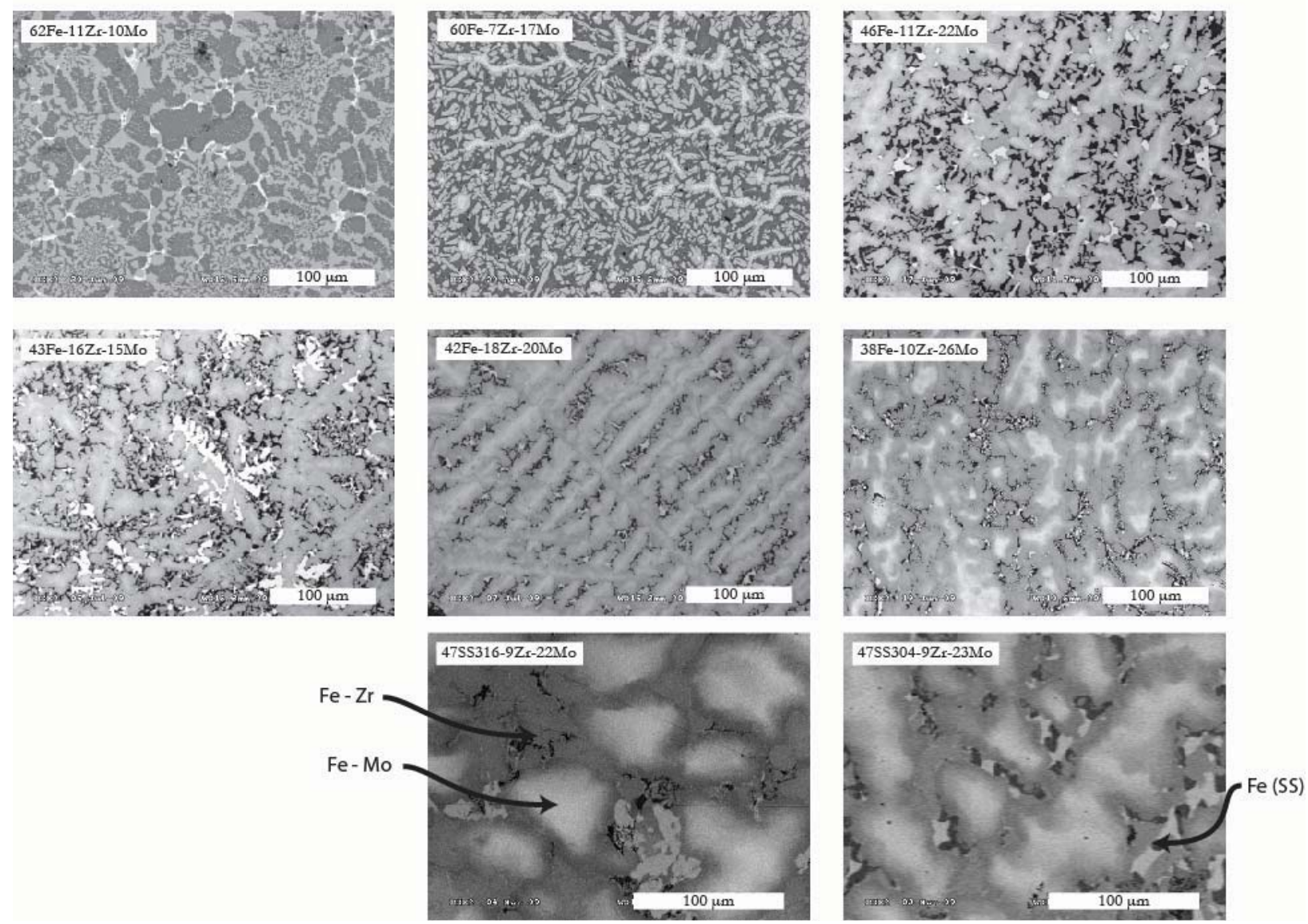

Figure 3 Electron micrographs of Fe-based alloys with compositions as indicated. The 47SS316 and the 47 SS304 specimens were made with $47 \mathrm{wt} \%$ powders of Type 316LSS and Type 304LSS, respectively. In addition, these specimens were held for approximately 1 hour at approximately $1000^{\circ} \mathrm{C}$ to stabilize the microstructure. White areas are Pd rich and black areas Fe rich. In the Fe 62 and 60 samples, light and dark gray visually distinguish the $\mathrm{Fe}_{2} \mathrm{Mo}$ and $\mathrm{Fe}_{2} \mathrm{Zr}$; however in the other images both phases are seen as gray.

Figure 4 shows the composition of the phases including all of the waste species incorporated into the alloys; the x-axis shows the various species and the y-axis shows the average of the amount of each element for each sample. Error bars on the plots represent the standard deviations of the averaging of the species in individual sample-phase data. As previously described, this sample set covers waste loading from 37-58 wt \% including 38-62 wt\% Fe, 7-18 wt $\% \mathrm{Zr}$ and 10-26 wt \% Mo. Stainless steel samples had $53 \%$ waste loading.

Figure 4 shows that all of the species partition in the same manner across this composition range. That is to say that the phases are the same without regard for the starting materials fractions (within the sample matrix). The Pd phase composition is reproduced from reference 4 for completeness. The EDS probed data collected on the Pd phase for the stainless steel specimens is suspected to have been heavily confounded by adjacent phases and is not reported here. The lack of other identified phases also suggests all of the starting material is incorporated into these phases. 

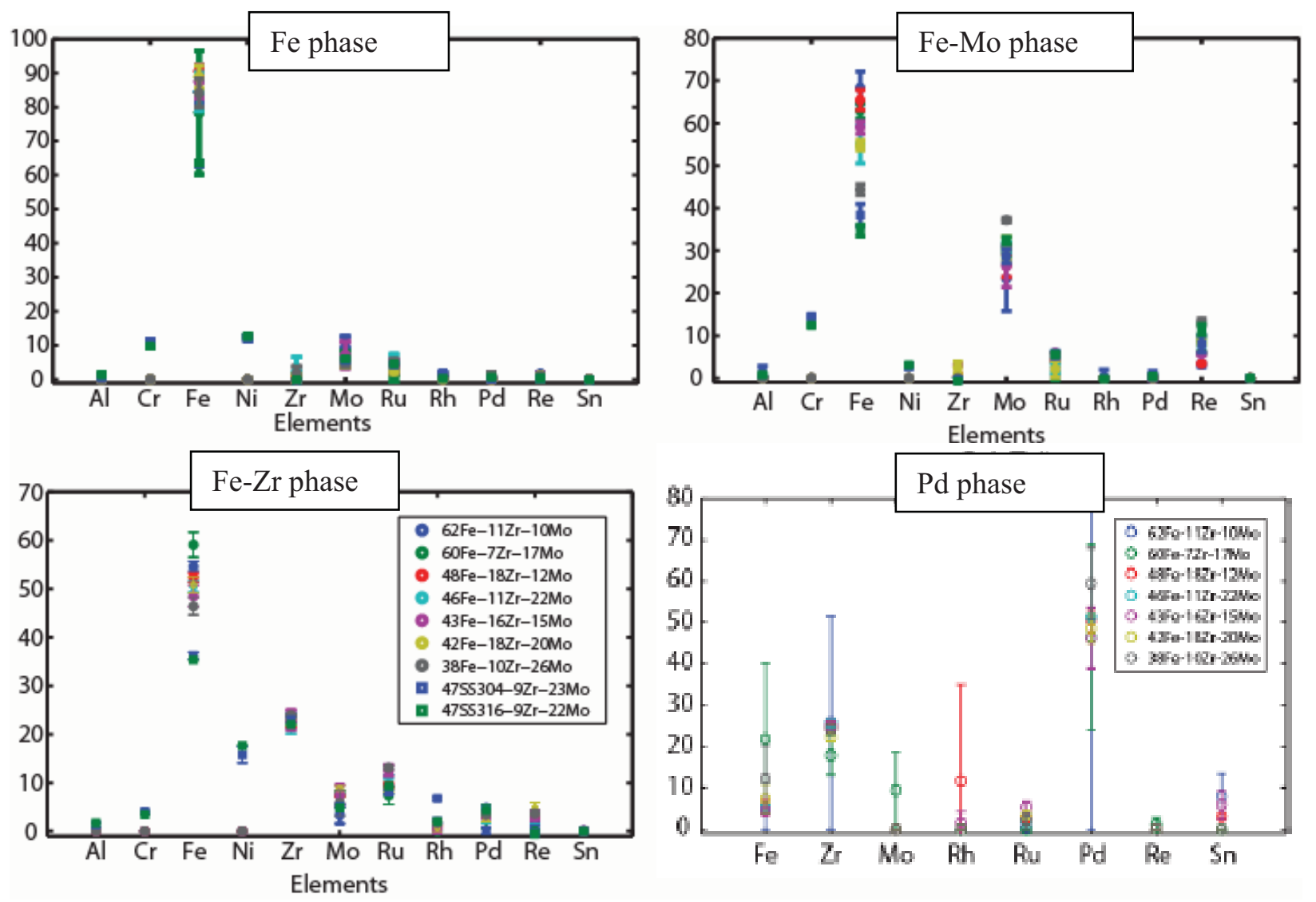

Figure 4 Plots showing the atomic percent of each element identified by EDS in the four major phases of the Fe-based waste form alloys

The oxidized samples were sectioned, mounted, and polished in cross-section in order to investigate the oxide characteristics. Oxides or passivation layers were not apparent in the SEM micrographs recorded at magnifications up to $15 \mathrm{KX}$ for either the sample exposed to steam for 7 or 14 days. The charging at the edge of the samples was believed to have interfered with obtaining a clear image. EDS data recorded within 2 microns of the surface of these samples displayed bulk type properties with little oxygen $(<2 \%)$ in all cases. Near surface imperfections were observed in the sample exposed for 28 days. Flakes of material were observed to contain $>65$ at $\%$ oxygen. A represented bulk microstructure of the oxidized specimens is shown in Figure 5. 


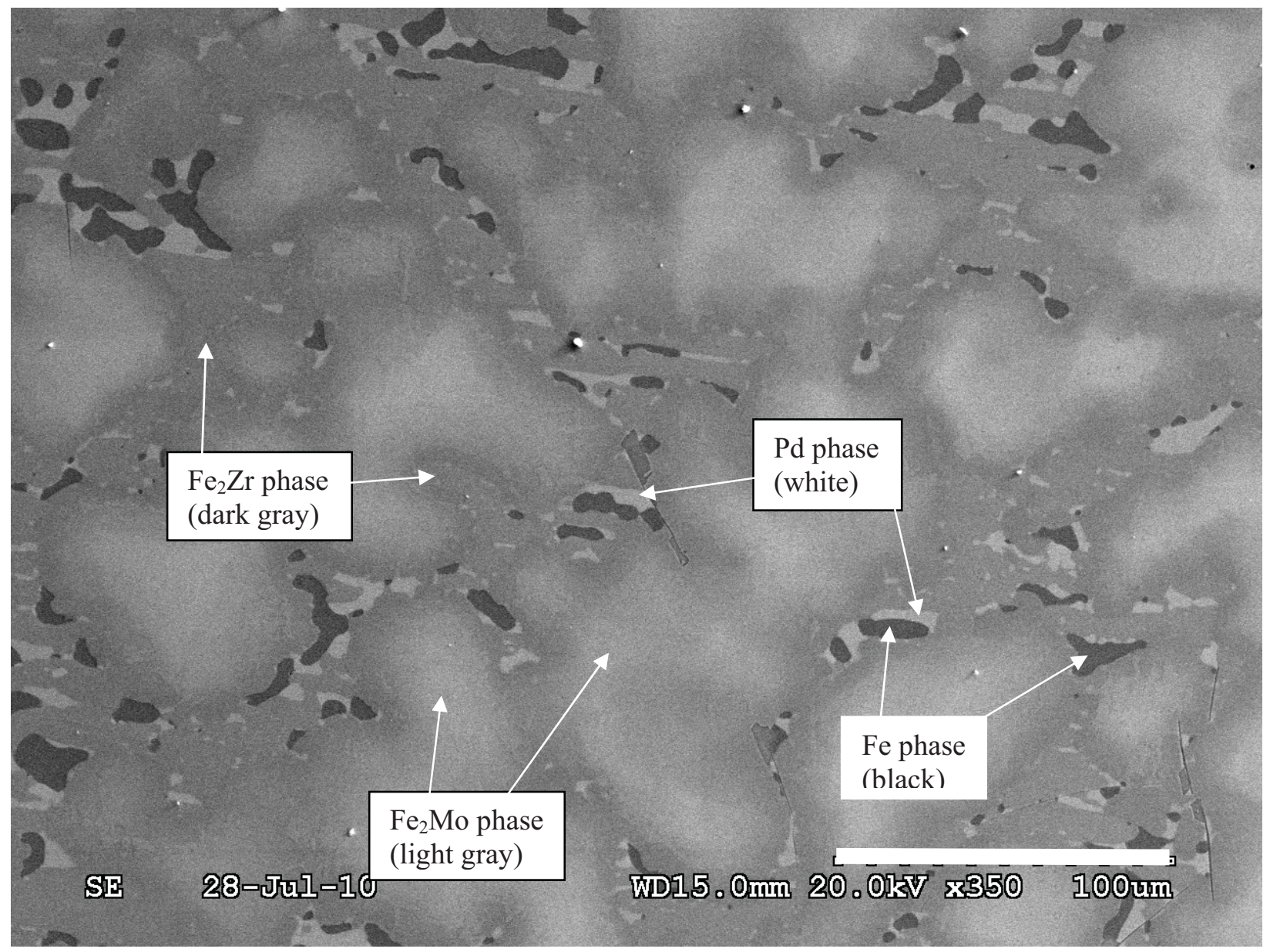

Figure 5 Bulk microstructure of the 28-day oxide specimen.

Table 3 shows representative EDS data from each of the cross section samples observed. The bulk material described here is shown as 47SS316-9Zr-22Mo in Figure 3. The bulk of the oxygen resides at the surface edges of grains that are high in Fe, and Fe-Mo. These grains also have higher levels of $\mathrm{Cr}$ than the Fe-Zr type grains. The edge oxides show particular enrichment in $\mathrm{Zr}$ content compared to its ratio in the bulk matrix in each of the grains. The edge oxides show a reduced Re enrichment.

Table 3 Representative EDS data (at.\%) from samples exposed to $200^{\circ} \mathrm{C}$ demineralized water at the indicated times. Data was recorded both at the exposed surface edge and bulk of grains

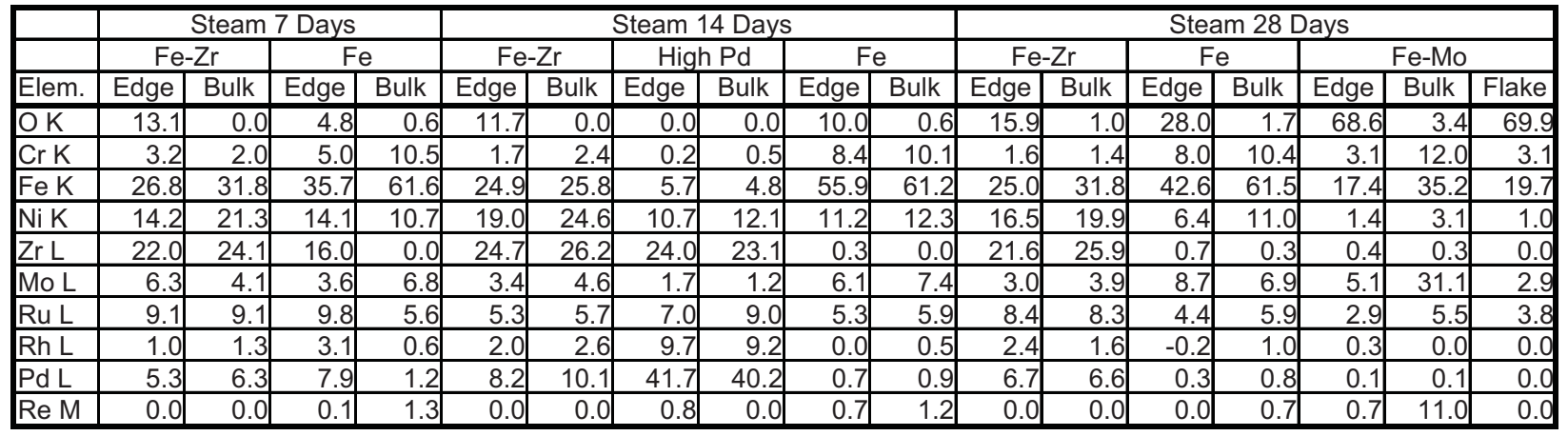




\subsection{Electrochemical Test Results}

The presence of an oxyhydroxide layer formed during aqueous corrosion of the metal altered the electrochemical corrosion response of the stainless steel waste form samples. The presence of the layer resulted in a stable corrosion potential that did not undergo an extended period of equilibration as shown by the open-circuit potential versus time data in Figure 6 below. In contrast, the freshly polished samples reacted with the solution to slowly enoble the potential, apparently through the formation of an oxydydroxide film. For the 28-day samples, the potential of the ground (repolished fresh) surface shifted approximately $90 \mathrm{mV}$ as they equilibrated in the $\mathrm{pH} 4$ solution.

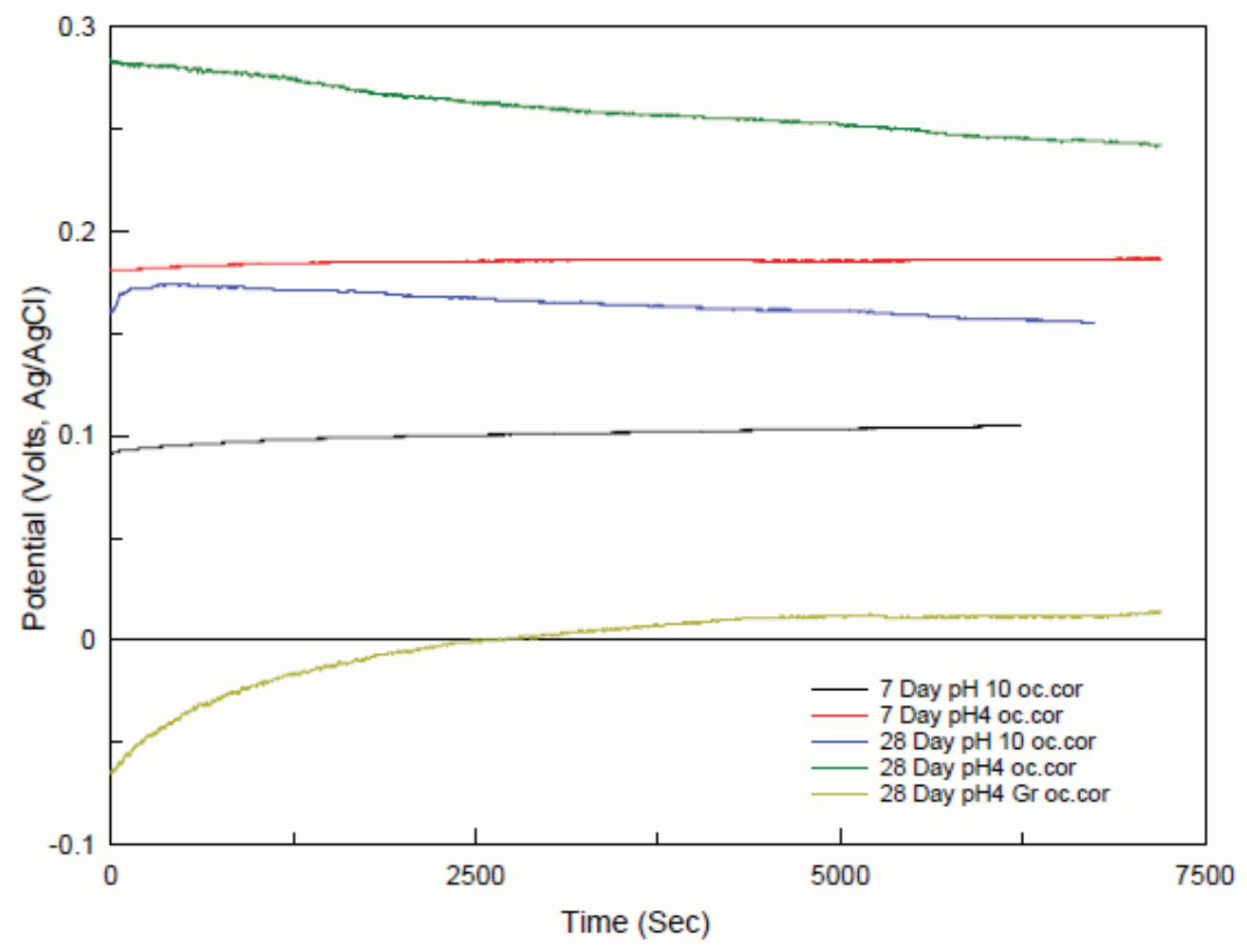

Figure 6 Open-circuit potential measurements of stainless steel alloyed waste forms prior to performing polarization tests.

Linear polarization resistance tests were performed to obtain a measure of the corrosion rate of these oxidized waste forms. Table 4 shows the polarization resistance (Rp), the calculated corrosion rate based on this resistance and the potential where current equals zero $(\mathrm{I}=0)$ for both the oxidized and non-oxidized samples.

The corrosion rates were similar in the $\mathrm{pH} 4$ and $\mathrm{pH} 10$ solution for the 28-day oxidized stainless steel sample. The corrosion rate increased in the $\mathrm{pH} 4$ solution with the removal of the oxide. For the nonoxidized samples, the corrosion rate is clearly a function of the solution $\mathrm{pH}$, increasing with increasing acidity. 
Table 4 Corrosion Rates and Electrochemical Parameters for Stainless Steel Alloyed Waste Forms in Acidic and Basic Solutions

\begin{tabular}{|c|c|c|c|c|}
\hline Solution & Sample & $\begin{array}{c}\mathbf{R p} \\
\left(\mathrm{Ohms} / \mathrm{cm}^{2}\right)\end{array}$ & $\begin{array}{c}\text { Potential }[\mathrm{I}=0] \\
(\mathrm{V}, \mathrm{Ag} / \mathrm{AgCl})\end{array}$ & $\begin{array}{c}\text { Corrosion Rate } \\
(\mu \mathrm{m} / \text { year })\end{array}$ \\
\hline \multirow{2}{*}{$\begin{array}{c}\text { pH 11* } \\
\text { (with } \mathrm{NaOH} \text { ) }\end{array}$} & 304L Non-Oxidized & $1.27 \mathrm{E} 5$ & -0.073 & 1.3 \\
\hline & 316L Non-Oxidized & $1.64 \mathrm{E} 5$ & -0.139 & 1.3 \\
\hline $\begin{array}{c}\text { pH } 10 \\
\text { (with } \mathrm{NaOH} \text { ) }\end{array}$ & 316L 28 day & $1.13 \mathrm{E} 5$ & 0.149 & 2.6 \\
\hline \multirow{2}{*}{$\begin{array}{c}\mathrm{pH} 4 \\
\text { (with sulfuric acid) }\end{array}$} & 316L 28 day & $1.41 \mathrm{E} 5$ & 0.241 & 2.1 \\
\hline & 316L Non-Oxidized & $9.38 \mathrm{E} 4$ & 0.012 & 3.2 \\
\hline \multirow{2}{*}{$\begin{array}{c}\text { pH } 3 * \\
\text { (with nitric acid) }\end{array}$} & 304L Non-Oxidized & $5.07 \mathrm{E} 4$ & 0.145 & 4.2 \\
\hline & 316L Non-Oxidized & $5.2 \mathrm{E} 4$ & 0.173 & 4.1 \\
\hline
\end{tabular}

* Data for testing performed end of FY2009 and not reported in ref [4] on non-oxidized samples

Cyclic potentiodynamic polarization were run on the stainless steel specimens for comparison with the electrochemical tests run with pure Fe used as the base waste form alloy. Figure 7 shows that the stainless steel waste forms displayed a passive behavior. Pure Fe alloys all displayed active dissolution. The presence of the oxide on the stainless steel waste forms shifted the polarization curve to higher potentials and lower current densities while still displaying passive behavior.
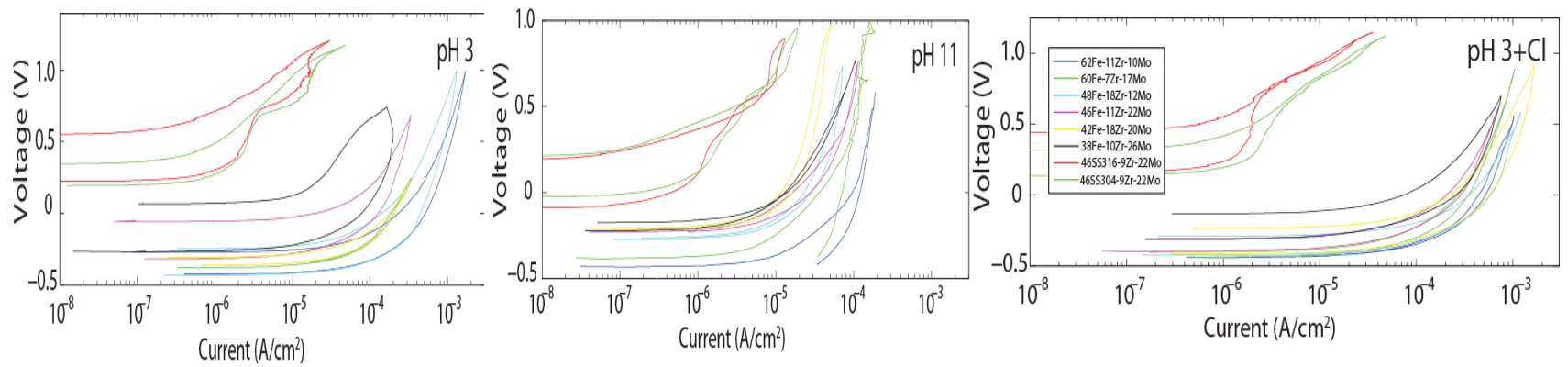

Figure 7 Cyclic potentiodynamic polarization scans of the stainless steel and iron waste forms. The solutions are pH 3 nitric acid solutions and pH 11 sodium hydroxide solutions. The voltage is against a Saturated Calomel Electrode (SCE) as the reference electrode. [SCE voltage $+0.045 \mathrm{~V}=\mathrm{Ag} / \mathrm{AgCl}$ voltage].

Figure 8 shows the cyclic polarization results for the 7- and 28-day samples in $\mathrm{pH} 10$ and $\mathrm{pH} 4$ solutions. The 0-day data presented in the figure are the data from FY2009 for the 304L based waste forms (also shown in Figure 8). As can be seen from the data, the 0- and 7-day data for both solution types (acidic and basic) are nearly identical. The corrosion potential of the 7-day samples are more noble, which is likely due to the presence of a thin oxide. Once the sample is polarized from this steady state condition, the oxide is insufficient to provide a barrier to the flow of current so the current densities are similar for these samples. The 28-day sample, however, had lower current densities for both solutions as well as the most noble corrosion potentials, which are associated with a thicker oxide layer. 

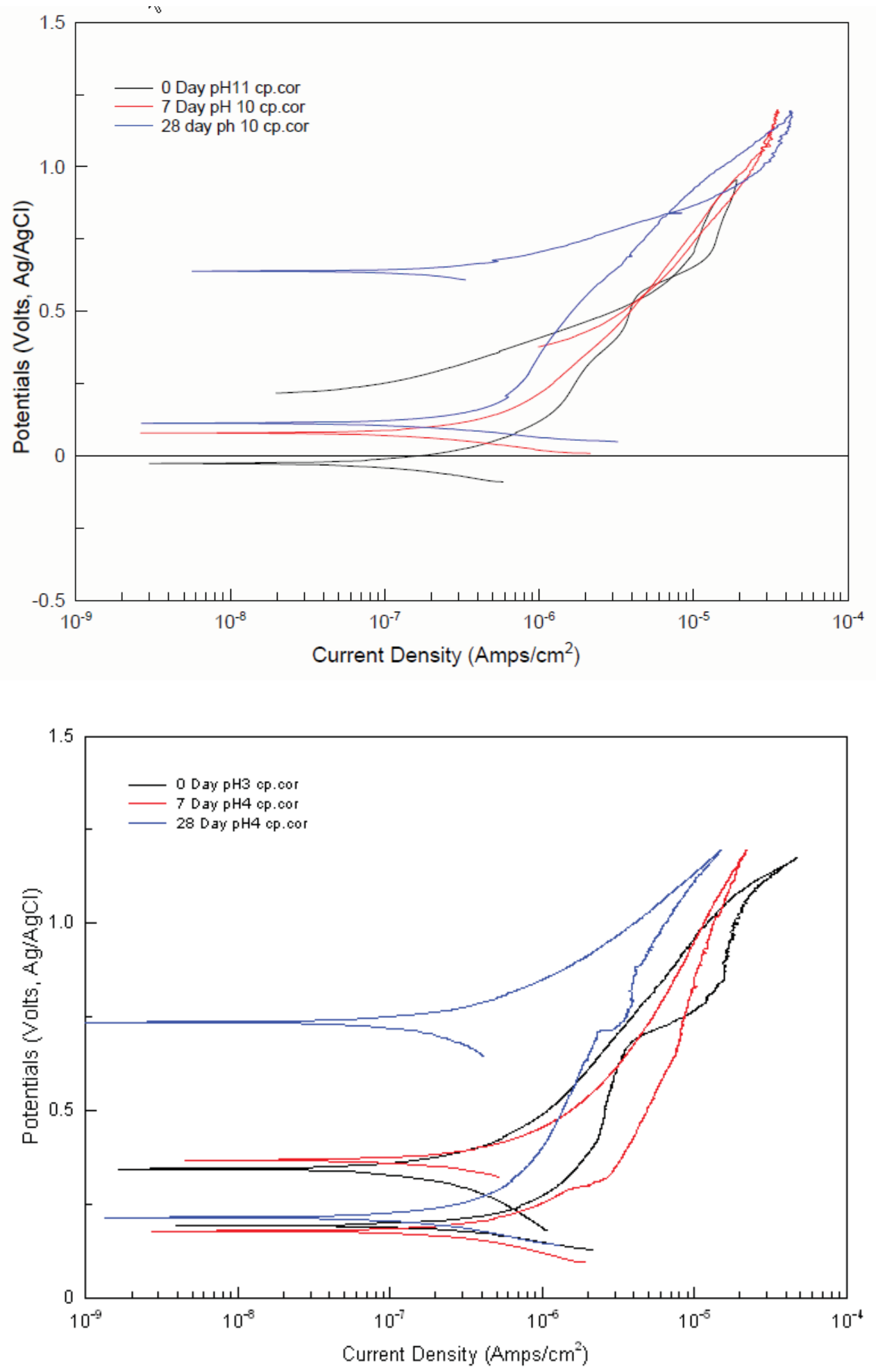

Figure 8 Cyclic polarization scans for oxidized stainless steel waste forms in basic (top plot) and acidic (bottom plot) solutions. 
Figure 9 shows the composite results from the 7-day and 28-day oxide specimens in the $\mathrm{pH} 4$ and $\mathrm{pH} 10$ solutions. The 28-day specimen was more noble than the 7-day specimen in both solutions with lower current densities, suggesting the oxide film on the 28-day specimen was more passivating than the 7-day specimen and was likely the results of a thicker film.

It is noted that at the peak voltage of $1.2 \mathrm{~V}$, the current of both specimens was the same, and it is possible that breakdown of the films may have started to occur. However, for the $\mathrm{pH} 4$ solution, the corrosion current throughout the entire anodic scan range was less for the 28-day specimen than the 7-day specimen. This suggests that film breakdown did not occur when these same specimens were first run in the $\mathrm{pH} 10$ solution.

The $\mathrm{pH} 10$ solution data for both specimens is at more active potentials and higher current densities than that for the $\mathrm{pH} 4$ solutions indicating the low concentration sulfuric acid solutions acts to form a more stable passive oxide film than the low concentration hydroxide solution at a $\mathrm{pH}$ of 10 .

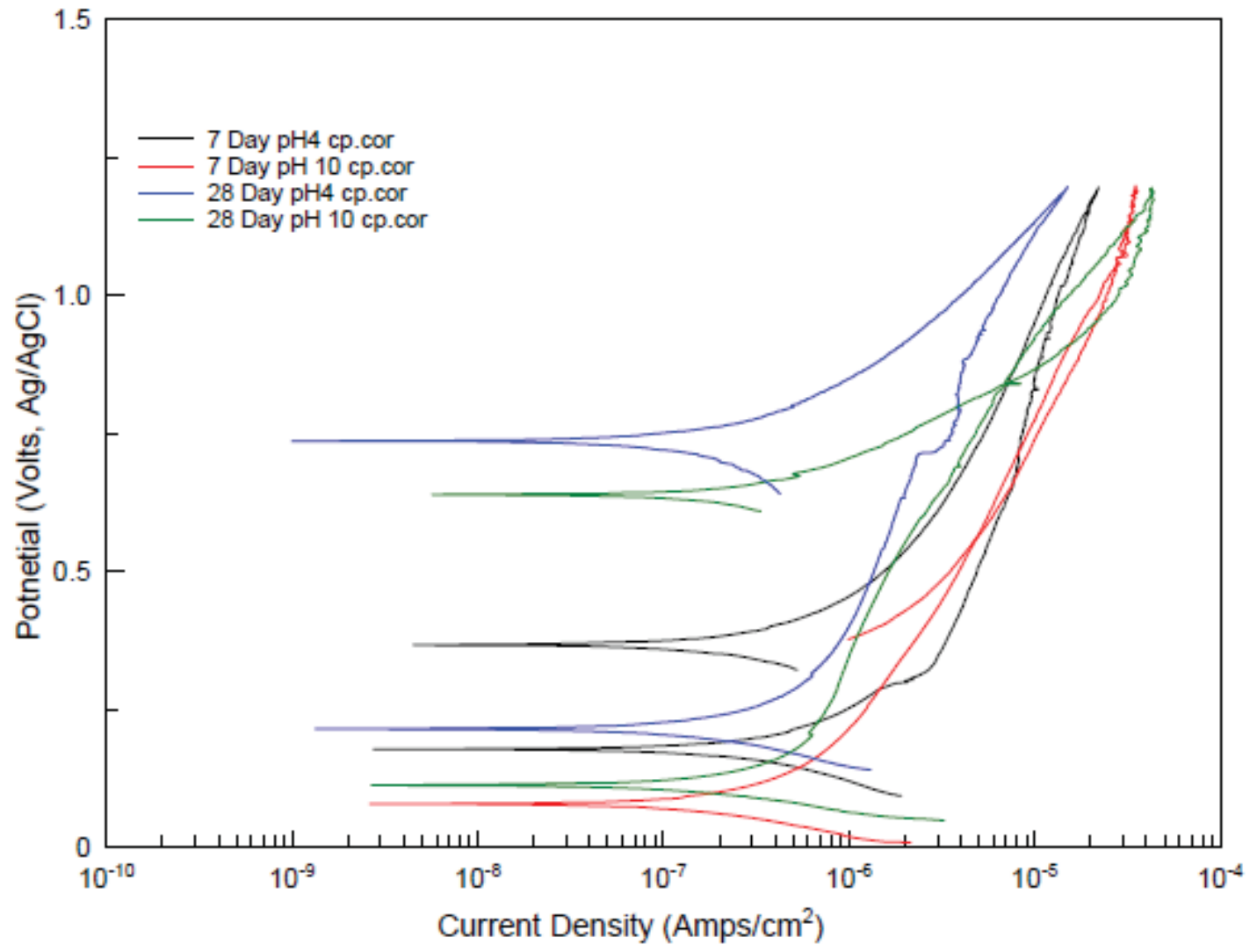

Figure 9 Composite cyclic polarization scans for the 7-day and 28-day oxidized stainless steel in pH 4 (using sulfuric) and pH 10 (using $\mathrm{NaOH}$ ).

\section{CONCLUSIONS}

A melt process to use 300-series stainless steel to incorporate metal waste species from used nuclear fuel recycle including those species from UDS and Tc and TRUEX waste was demonstrated. Species melted in this study included Fe, $\mathrm{Zr}$, Mo, Tc (using Re), Rh, Ru, and Pd with a total waste loading of 53\% in both Type $316 \mathrm{~L}$ and $304 \mathrm{~L}$ stainless steels. Four primary phases were formed, and all metallic species were 
incorporated into the phase assemblage with a vacuum melt process at $1600^{\circ} \mathrm{C}$. The melt sample microstructure was homogeneous (uniform) throughout the volume of the 50 gram melts.

Samples of the Fe-based waste form with Type 316 stainless steel were exposed to demineralized water at $200^{\circ} \mathrm{C}$ for times of 7, 14, and 28 days. The results from SEM-EDS analysis showed an increase in an apparent oxyhydroxide film thickness with exposure time, although quantitative film thicknesses were not obtainable due to surface charging effects. The effect of the oxide to passivate the specimens was clearly evident with the 28-day specimen showing the greatest passivation effects in terms of enobling the metal in an open circuit, and lowering the corrosion current during cyclic polarization in both the basic $(\mathrm{pH} 10)$ solutions of $\mathrm{NaOH}$ in demineralized water and acidic $(\mathrm{pH} 4)$ solutions of sulfuric acid in demineralized water.

Qualitatively, the oxides showed particular enrichment in $\mathrm{Zr}$ content compared to its ratio in the bulk matrix in each of the grains. The edge oxides show a reduced Re enrichment compared to its ratio in the bulk matrix of the Fe-Mo grains. This suggests that an incongruence in specie release compared to the alloy composition may occur in this alloy waste form.

This initial work has demonstrated that a thin, adherent passive film can form on the Fe-based alloy, and that the film retards the corrosion rate as compared to the fresh ground surface in water solutions at low and high $\mathrm{pH}$. Additional characterization of the oxyhydroxide film layered structure over the crystalline phases, and additional corrosion testing at additional aqueous conditions identified for alloy waste form consistency testing, should be pursued to build the information base for alloy waste form durability.

\section{REFERENCES}

${ }^{1}$ http://www.nuclear.gov/fuelcycle/neFuelCycle.html

${ }^{2}$ Vienna, J., Waste Forms Campaign Implementation Plan, FCRD-WAST-2010-000043, March 2010.

${ }^{3}$ Gombert, D., II, et al., Global Nuclear Energy Partnership Integrated Waste Management Strategy Waste Treatment Baseline Study, Volume I, GNEP-WAST-AI-RT-2007-000324, September 2007.

${ }^{4}$ Williamson, M.J. and Sindelar, R.L., Development of an Fe-Based Alloy Waste Form for Spent Nuclear Fuel, AFCI-SEPA-WAST-MI-DV-2009-000143, SRNL-STI-2009-00522, August 2009

${ }^{5}$ Buck, E.C. and Neiner, D., Technetium Waste Form Development - Progress Report, FCR\&DPN0915030312, April 2010. 